\title{
Fire resistance of ultra-high performance fibre reinforced concrete due to heating and cooling
}

\author{
Fadzli Mohamed Nazri ${ }^{1, a}$, Ramadhansyah Putra Jaya ${ }^{2}$, Badorul Hisham Abu Bakar ${ }^{1}$, Raudhah Ahmadi ${ }^{3}$ \\ ${ }^{1}$ School of Civil Engineering, Engineering Campus, Universiti Sains Malaysia, 14300 Nibong Tebal, Penang \\ ${ }^{2}$ Faculty of Civil Engineering, Universiti Teknologi Malaysia, 81310 Skudai, Johor. \\ ${ }^{3}$ Department of Civil Engineering, Universiti Malaysia Sarawak, 94300 Kota Samarahan, Sarawak.
}

\begin{abstract}
This study investigated the performance of ultra-high performance fibre reinforced concrete (UHPFRC) at elevated temperatures. The specimens were exposed to high temperatures, specifically 200,400 , and $600{ }^{\circ} \mathrm{C}$, for 2 h.The fire resistance performance of the specimens was classified on the basis of their compressive strength, spalling, and weight loss; residual strength after heating was also examined. Results showed that UHPFRC processes excellent fire resistance in terms of flame spread and fire growth. While strength loss was not significant at low temperatures, the specimen subjected to high temperature spalled severly and showed deterioration because of heat.
\end{abstract}

\section{Introduction}

Ultra-high-performance fiber-reinforced concrete (UHPFRC) is a breakthrough in modern concrete mix design with compressive strengths benchmarking 150 $\mathrm{MPa}$ and above and tensile strengths of over $10 \mathrm{MPa}$. Previous studies clearly show the advantages of using high-performance fiber-reinforced cementitious composites, such as UHPFRC, engineered cementitious composites, and slurry-infiltrated concrete, in structural members under static loading conditions [1-3]. In a related study, [4] found that UHPFRC has outstanding material characteristics, such as self-consolidating workability, very high mechanical properties, and low permeability, all of which result in excellent environmental resistance. Millon et al. [5] reported that UHPFRC can significantly improve the impact resistance of cladding panels and walls while maintaining its standard thickness and appearance. UHPFRC is a cementitious composite reinforced by fibers with characteristic values exceeding $150 \quad \mathrm{~N} / \mathrm{mm}^{2}$ in compressive strength, $5 \mathrm{~N} / \mathrm{mm}^{2}$ in tensile strength, and 4 $\mathrm{N} / \mathrm{mm}^{2}$ in first cracking strength [6]. This concrete also shows compressive strengths over seven times and tensile strengths greater than three times those of conventional concrete [4]. The fibers in UHPC provide tensile capacity across cracks, resulting in high shear capacity in bending members. These fibers improve tensile strength. Parsekian et al. [7] reported that small brass-coated steel fibers with a diameter of $0.185 \mathrm{~mm}$ and a length of 14 $\mathrm{mm}$ are commonly used as reinforcements in UHPC. Synthetic fiber and poly-vinyl alcohol have also been used [8]. The high compressive strength of UHPFRC is achieved by the densely packed state of the cement matrix, and its tensile strength is attributed to steel or polypropene fibers embedded in the matrix. The superior characteristics of UHPRFC allow its use in different applications that demand high strength and durability, including bridges, tunnels, and high-rise buildings. Massive structures may be at risk and endanger lives if UHPFRC is not resistant to fire exposure. Conventional fiber-reinforced concrete exhibits good capacity to absorb impact energy [9].

Despite the positive characteristics of these structures, they are still susceptible to fire. Fire exposure induces temperatures of up to $1000{ }^{\circ} \mathrm{C}$, which could be detrimental to the structural integrity of UHPFRC. Water stored in the fine pores of the dense matrix evaporates under temperature extremities, and pressure builds up internally. When stresses cannot be withstood, explosion of concrete follows, a phenomenon known as spalling. Unfortunately, spalling is unpredictable; it can occur during the heating or cooling of UHPFRC. The behavior of UHPFRC during and after fire exposure requires further study to fully understand the mechanism of failure and risks in using this concrete [10].

The present research principally focuses on the fire reactions of UHPFRC. In this work, two types of UHPFRC mixes are prepared and subsequently subjected to high temperatures and fire resistance tests to observe their physical characteristics, spalling, and strength loss. Considering that the behavior of the concrete under fire is unknown, this research assists in understanding how the product behaves during fire. Use of UHPFRC not only reduces the amount of concrete required but also increases the serviceability and durability of the resulting structures. Understanding fire resistance is crucial to gain

\footnotetext{
a Corresponding author: cefmn@usm.my
} 
confidence in the reliability of the product as a future replacement for conventional OPC.

\section{Methodology}

UHPFRC was prepared in accordance with the mix design shown in Table 1.

Table 1. Mix proportions of UHPFRC

\begin{tabular}{|c|c|}
\hline Materials & $\mathbf{K g} / \mathbf{m}^{\mathbf{3}}$ \\
\hline Cement & 768 \\
\hline Silica Fume & 192 \\
\hline Steel Fiber (vol\%) & $2 \%$ \\
\hline White sand & 1140 \\
\hline Superplasticizer (vol\%) & $1.9 \%$ \\
\hline Water & 145 \\
\hline Water/binder ratio & 0.15 \\
\hline Total binder amount & 960 \\
\hline
\end{tabular}

The materials were mixed in a drum mixer in the following order: cement, silica fume, and sand. These materials were dry mixed until they were homogeneous. Pre-mixed superplasticizer and water were added and mixing was continued until no dry materials remained. Finally, the steel fibers were added and mixed. The mixing process took $15 \mathrm{~min}$.

Finished batches were poured into a concrete bucket and then placed into a wheelbarrow. Cubic molds were filled using hand shovels. No vibration was included during placement because the concrete is selfconsolidating. The specimens were cured by steam curing for $48 \mathrm{~h}$ at a temperature of $90^{\circ} \mathrm{C}$ and a relative humidity of $100 \%$. Then, the specimens were cured in water maintained at a room temperature of $27 \pm 2{ }^{\circ} \mathrm{C}$ until the testing day. The specimens were cast on the basis of the four tests. For the first test (i.e., a furnace fire test), 24 cube specimens were prepared. Two specimens from the two mix designs were exposed to a temperature of 200 ${ }^{\circ} \mathrm{C}$. Then, the test was repeated at 400 and $600{ }^{\circ} \mathrm{C}$. This test was repeated once more. The three tests related to BS476 fire testing of building materials and structures comprised the sizes and quantities described in Table 2.

Table 2. Quantity of specimens required for BS 476 fire reaction tests

\begin{tabular}{|c|c|c|}
\hline $\begin{array}{c}\text { BS 476 Fire Reaction } \\
\text { Tests }\end{array}$ & Size of Specimen & Quantity \\
\hline $\begin{array}{c}\text { Part 4 (Non- } \\
\text { Combustibility test) }\end{array}$ & $\begin{array}{c}40 \mathrm{~mm} \times 40 \mathrm{~mm} \times \\
50 \mathrm{~mm}(\mathrm{~h})\end{array}$ & 3 \\
\hline $\begin{array}{c}\text { Part 6 (Method of test for } \\
\text { fire propagation of } \\
\text { products) }\end{array}$ & $\begin{array}{c}225 \mathrm{~mm} \times 225 \mathrm{~mm} \times \\
50 \mathrm{~mm}(\text { thk })\end{array}$ & 3 \\
\hline $\begin{array}{c}\text { Part 7 (Method for } \\
\text { classification of the } \\
\text { surface spread of flame of } \\
\text { products) }\end{array}$ & $\begin{array}{c}885 \mathrm{~mm} \times 225 \mathrm{~mm} \times \\
50 \mathrm{~mm}(\text { thk })\end{array}$ & 6 \\
\hline
\end{tabular}

The mix quality of self-consolidating concretes is frequently assessed through a slump cone flow test., The newer BS EN 12350-8:2010 test is commonly used with UHPFRC. This test measures self-compacting concrete. An initial flow reading and a dynamic flow reading were recorded. This test was completed immediately after mixing to assess the consistency between mixes and appropriateness for casting. Compressive strength is arguably the most readily captured and used property of concrete. Standard concrete compression testing methods (i.e., BS 1881-119:2011) are applicable to UHPFRC. However, these test methods may benefit from slight modification to facilitate efficient use. A loading rate of 1 $\mathrm{MPa} / \mathrm{s}$ is acceptable and allows for individual tests to be completed within a reasonable timeframe.

At the high strength levels achieved with UHPFRC, cube compressive tests are an appropriate substitute for cylinder compression tests. Companion cylinder and cube strength results tend to be within $5 \%$ of one another, thereby allowing for direct substitution of results. The high compressive strengths of UHPC may necessitate the use of high-capacity compression testing plates and machines. The furnace test is a method in which UHPFRC samples are heated at specific temperatures to observe their physical properties and behavior as a function of heat. The furnace used was a ThermConcept $\mathrm{KC} 80 / 14$, as illustrated in Figure 1. The furnace specifications are tabulated in Table 3.

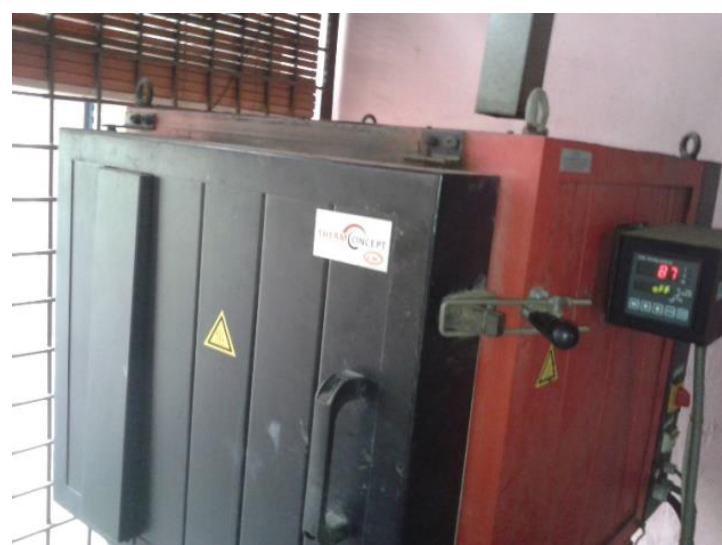

Figure 1. ThermConcept KC 80/14 furnace used in this work

Table 3. Specifications of the ThermConcept KC 80/14 furnace

\begin{tabular}{|c|c|}
\hline Model & KC 80/14 \\
\hline T max $\left({ }^{\circ} \mathbf{C}\right)$ & 1400 \\
\hline $\begin{array}{c}\text { Inside dimensions } \\
(\mathbf{w} \times \text { d } \mathbf{~ h})\end{array}$ & $430 \times 430 \times 430$ \\
\hline Liter (L) & 80 \\
\hline $\begin{array}{c}\text { External dimensions } \\
(\mathbf{w} \times \mathbf{~ d ~ x ~ h ) ~}\end{array}$ & $985 \times 1066 \times 1540$ \\
\hline Power $(\mathbf{k W})$ & 280 \\
\hline Weight (kg) & $4003 / \mathrm{N}$ \\
\hline Volatege (V) & \\
\hline
\end{tabular}

The specimens were placed in the furnace for $2 \mathrm{~h}$ at varying temperatures, specifically 200,400 , and $600{ }^{\circ} \mathrm{C}$. Four specimens were used for every temperature. The experiment was repeated twice with a different batch mix. After heating, the specimens were allowed to cool to 
below $70^{\circ} \mathrm{C}$ and subsequently removed from the furnace. The spalling behavior, residual mass, and residual compressive strength of the samples were then observed, noted, and tested accordingly.

\subsection{Fire reaction tests in BS 476: Fire tests on building materials and structures}

Materials used in the construction and finishing of buildings or structures are classified as "noncombustible" or "combustible" on the basis of their behavior in the non-combustibility test. To begin, the size of specimens illustrated in Figure 2 was heated, and its temperature was stabilized at $750 \pm 10^{\circ} \mathrm{C}$ for a minimum period of $10 \mathrm{~min}$.

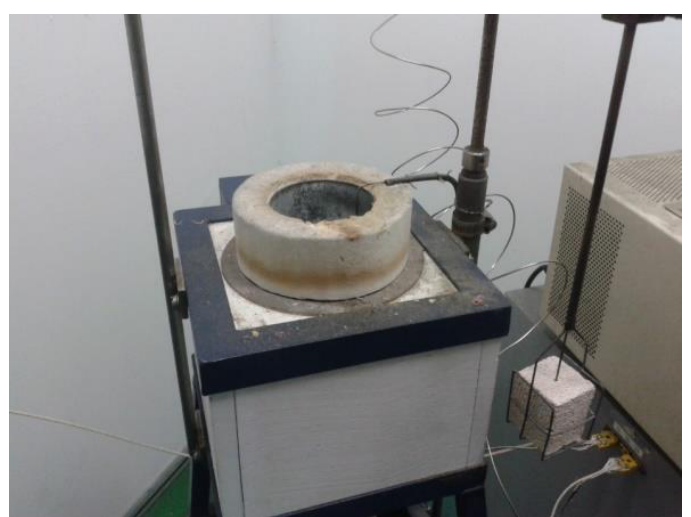

Figure 2. Size of specimens used for the non-conmbustibility test : $40 \mathrm{~mm}(\mathrm{l}) \times 40 \mathrm{~mm}(\mathrm{w}) \times 50 \mathrm{~mm}(\mathrm{~h})$.

The specimen was then inserted in the furnace. The whole operation required no more than $5 \mathrm{~s}$. A record of the temperature of the two thermocouples was made over the next 20 min using a continuous recorder. The occurrence and duration of any flaming in the furnace were noted. The stabilized heating current remained unchanged throughout the duration of the test. The material was deemed non-combustible if, during the test, none of the three specimens either:

i. caused the temperature reading from either of the two thermocouples to rise by $50{ }^{\circ} \mathrm{C}$ or more above the initial furnace temperature, or

ii. continuously flamed for $10 \mathrm{~s}$ or more inside the furnace. Otherwise, the material was deemed combustible.

Before the test, specimens were dried in a ventilated oven at $60 \pm 5{ }^{\circ} \mathrm{C}$ for $24 \mathrm{~h}$ and then cooled to ambient temperature in a desiccator containing anhydrous calcium chloride.

Results are expressed as a fire propagation index, which provides a comparative measure of the contribution to the growth of fire made by an essentially flat material, composite, or assembly. This index is primarily intended for assessing the performance of internal wall and ceiling linings. The test apparatus is illustrated in Figure 3.

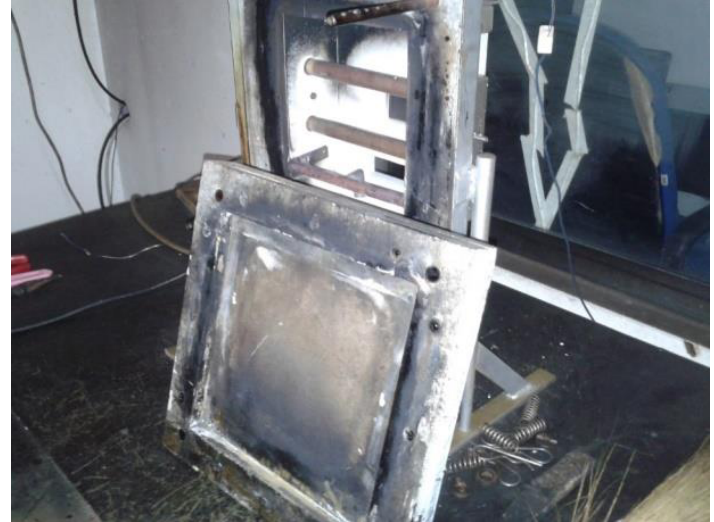

Figure 3. Fire propagation test for a specimen measuring $225 \mathrm{~mm}$ x $225 \mathrm{~mm}$ x $50 \mathrm{~mm}$

The thermocouple output indicator was turned on, and the initial output Ei (expressed in $\mathrm{mV}$ ) was recorded, as measured by the thermocouples inside the cowl. After allowing any residual gas within the combustion chamber to disperse, the gas supply was turned on and the jets were ignited using the gas igniter. The test was timed from the time of ignition. After $2 \mathrm{~min}$ and $45 \mathrm{~s}$, the electrical supply was turned on to produce an indicated input of $1800 \mathrm{~W}$. About 5 min after the time of ignition, the input was reduced to $1500 \mathrm{~W}$. The output was recorded from the thermocouples, $\mathrm{Er}$, in $\mathrm{mV}$, at the following points:

a) $0.5 \mathrm{~min}$ intervals, up to and including $3 \mathrm{~min}$ from the time at which the gas was ignited;

b) $1 \mathrm{~min}$ intervals, up to $10 \mathrm{~min}$ from the time at which the gas was ignited; and

c) 2 min intervals, up to $20 \mathrm{~min}$ from the time at which the gas was ignited.

BS 476 Part 7 specifies a test method for measuring the lateral spread of flame along the surface of a specimen of a product orientated in the vertical position, as illustrated in Figure 4, and provides a classification system based on the rate and extent of flame spread.

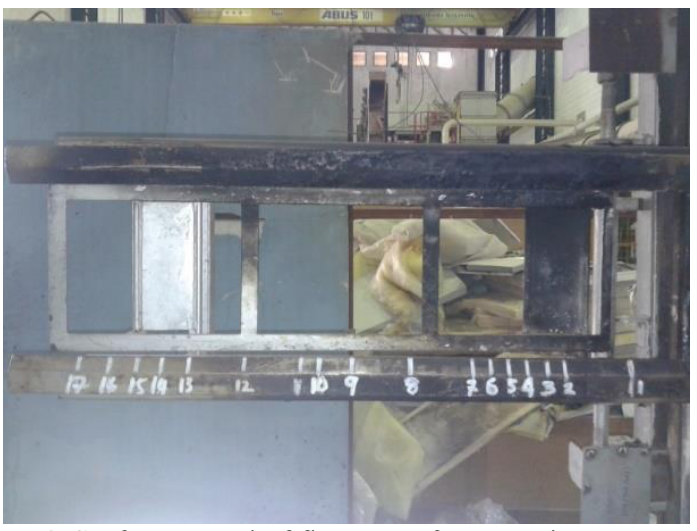

Figure 4. Surface spread of flame test for a specimen measuring $825 \mathrm{~mm}$ x $225 \mathrm{~mm}$ x $50 \mathrm{~mm}$ 
This standard provides data suitable for comparing the performances of essentially flat materials, composites, or assemblies that are primarily used as the exposed surfaces of walls or ceilings.

In practice, standard testing methods are used to determine the fire performance of materials and building or structural elements. These methods replicate the conditions of typical fires, either on a smaller scale (e.g., in a specially built oven/furnace) or in a full-scale test (i.e., on a part or whole mock-up of a building).

i. ISO 834 or BS 476:1987: Fire tests on building materials and structures.

ii. BS EN 1363-1:2012: Fire resistance tests

iii. BS 1881:1983: Testing Concrete.

iv. ASTM C150 / C150M - 12 Standard Specification for Portland Cement.

\section{Results and discussion}

\subsection{Development of optimum mix design}

Park et al. [11] explained that the strength of UHPFRC depends on the interface failures between the cement paste and aggregates. A low water-to-cement ratio reduces the size of inter-transition zones between the cement particles and aggregates and subsequently maximizes the strength development of the UHPFRC. The mix designs are specified in Table 4 below.

Table 4. Mix design of UHPFRC samples.

\begin{tabular}{|c|c|c|}
\hline Materials & $\begin{array}{c}\text { Mix A } \\
\mathrm{kg} / \mathrm{m}^{3}\end{array}$ & $\begin{array}{c}\mathrm{Mix} \mathrm{B} \\
\mathrm{kg} / \mathrm{m}^{3}\end{array}$ \\
\hline Cement & 768 & 875 \\
\hline Silica Fume & 192 & 190 \\
\hline $\begin{array}{c}\text { Steel Fiber } \\
\text { (vol\%) }\end{array}$ & $2 \%$ & $2.5 \%$ \\
\hline $\begin{array}{c}\text { White Sand } \\
\text { Superplasticizer } \\
\text { (vol\%) }\end{array}$ & 1140 & 1272 \\
\hline Water & $14 \%$ & $1.9 \%$ \\
\hline $\begin{array}{c}\text { Water/binder ratio } \\
\text { Total binder } \\
\text { amount }\end{array}$ & 0.15 & 0.17 \\
\hline
\end{tabular}

\subsection{Compressive strength}

The average values obtained are illustrated in Table 5.

Table 5. Average compressive strength of UHPFRC cubes.

\begin{tabular}{|c|c|c|}
\hline $\begin{array}{c}\text { Time } \\
\text { (Days) }\end{array}$ & $\begin{array}{c}\text { Mix A } \\
\text { (MPa) }\end{array}$ & $\begin{array}{c}\text { Mix B } \\
\text { (MPa) }\end{array}$ \\
\hline 7 & 131 & 127 \\
\hline 28 & 152 & 161 \\
\hline
\end{tabular}

The compressive strength of UHPFRC, at above 150 $\mathrm{MPa}$, is satisfactory. Mix A showed a compressive strength of $152 \mathrm{MPa}$, while Mix B showed a strength of $161 \mathrm{MPa}$ after $28 \mathrm{~d}$. The higher strength development at $28 \mathrm{~d}$ in Mix B is most likely due to the higher cement content packed per cube of Mix B samples. Mix B has a higher binder amount than Mix A. Silica fume was maintained at equal levels for both mixes because of the physical and chemical aspects of the silica fume itself. First, silica fume undergoes a pozzolanic reaction in the presence of calcium hydroxide during cement hydration. Addition of silica fume when the calcium hydroxide required for the pozzolanic reaction is relatively fixed could be redundant and decrease the compressive strength. The particle size of the silica fume is very small, and the silica can increase the packing density of the material when the cement is substituted. Packing effects can increase the compressive strength of UHPFRC, lower its permeability, and increase its durability. Steel fibers of $0.2 \mathrm{~mm}$ diameter at $2 \%$ and $2.5 \%$ of the total volume were used in Mixes $\mathrm{A}$ and $\mathrm{B}$, respectively. The percentages of steel fiber were adopted from $\mathrm{Yu}$ et al. [12] in their study on optimized UHPFRC. The $2 \%$ steel fiber amount is an optimized value practiced at the industry and research levels.

Steel fibers play an important role in the $28 \mathrm{~d}$ compressive strength of UHPFRC. Steel fibers also contribute to the tensile strength of the concrete. Ultimately, the main contributors to UHPFRC strength are a low water-to-cement ratio and the highly dense state of the cement.

\subsection{Spalling}

UHPFRC cubes measuring $100 \mathrm{~mm} \times 100 \mathrm{~mm} \times$ $100 \mathrm{~mm}$ were placed in a furnace at 200,400 , and $600{ }^{\circ} \mathrm{C}$ for $120 \mathrm{~min}$ at a rate of $15^{\circ} \mathrm{C} / \mathrm{min}$. The furnace test was performed with both mixes $\mathrm{A}$ and $\mathrm{B}$ (two samples for each mix) and repeated twice at three temperatures, yielding a total of 24 samples. All samples were allowed to cool until ambient temperature before removal from the furnace. At a low temperature of $200{ }^{\circ} \mathrm{C}$, the concrete was observed to be in perfect condition despite some discoloration. This sample appeared greyish-white after being exposed at $200{ }^{\circ} \mathrm{C}$ for $2 \mathrm{~h}$. However, at very high temperatures of 400 and $600{ }^{\circ} \mathrm{C}$, the concrete underwent severe spalling. The concrete cubes became unrecognizable and completely deteriorated at high temperatures. All physical behaviors described above are illustrated in Figures 5 to 9.

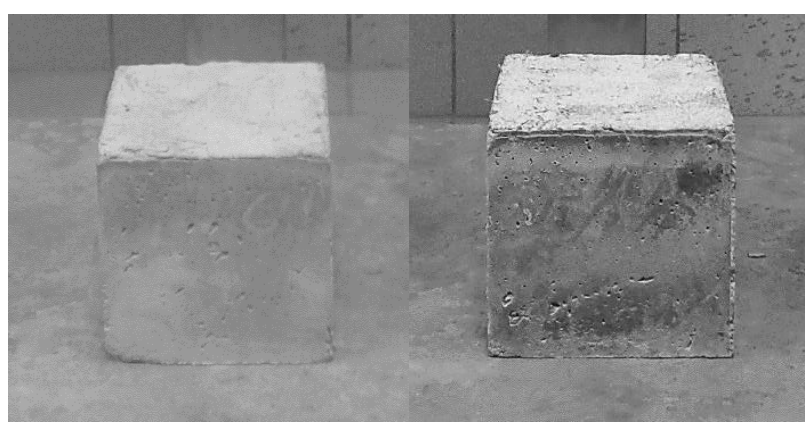

Figure 5. UHPFRC before and after exposure to $200{ }^{\circ} \mathrm{C}$ temperature. 


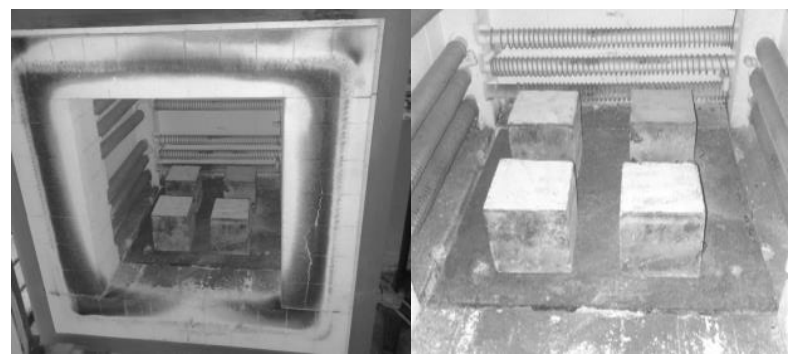

Figure 6. UHPFRC before and after exposure to $200{ }^{\circ} \mathrm{C}$ temperature.

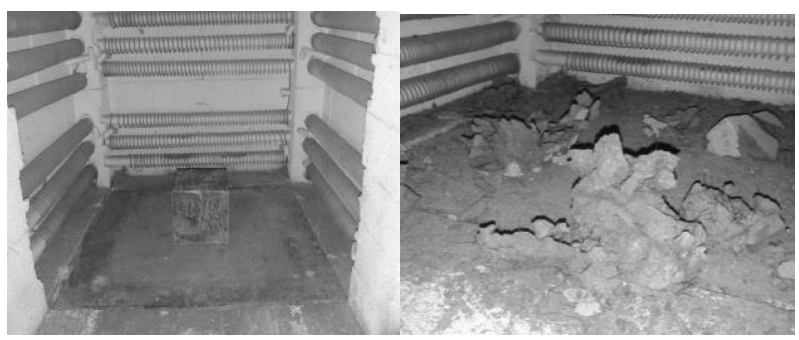

Figure 7. UHPFRC before and after exposure to $400{ }^{\circ} \mathrm{C}$ temperature.

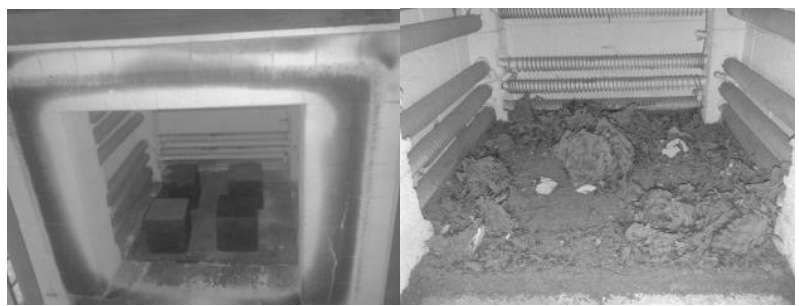

Figure 8. UHPFRC before and after exposure to $600{ }^{\circ} \mathrm{C}$ temperature.

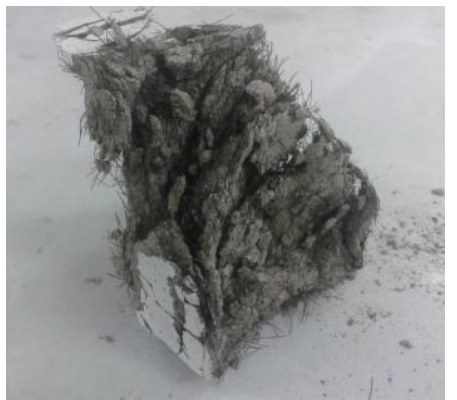

Figure 9. Core sample of UHPFRC recovered after exposure to $600{ }^{\circ} \mathrm{C}$.

The low porosity of UHPFRC induces great internal stresses. When pores completely closed, water vapor cannot escape during heating. Increases in pressure within the material cause spalling. Polypropylene fibers are effective in reducing spalling because these fibers melt and provide escape routes for trapped steam. These fibers create additional capillary pores in the matrix. However, a different phenomenon was observed in the UHPFRC meshed with steel fibers. The concrete underwent severe spalling at 400 and $600{ }^{\circ} \mathrm{C}$ until the specimen was destroyed beyond recognition. This result shows that UHPFRC fire resistance is unfavorable when subjected to high fire loadings primarily because of its very dense and brittle material. Steel fibers remained in good condition without much distortion from the heat. The color of these fibers was a dark rusty brown. This color can be attributed to Fe oxidation in the steel fibers to $\mathrm{FeO}$.

\subsection{Mass and strength loss}

Mass loss was apparent after subjecting the samples to high heat loadings. Two representative samples, $\mathrm{P}$ and Q, were weighed before the samples were heated. The test was repeated twice. Figure 10 shows the standard weighing process of the cubic samples.

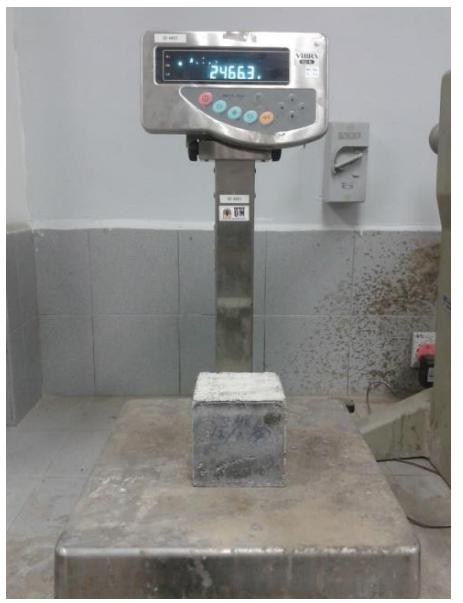

Figure 10. Standard weighing process of UHPFRC samples.

Table 6 summarizes the mass loss data before and after heating.

Table 6. Mass of various UHPFRC samples before and after the furnace test.

\begin{tabular}{|c|c|c|c|c|c|c|c|c|}
\hline \multicolumn{3}{|c|}{ Mix Type } & \multicolumn{6}{|c|}{ Temperature } \\
\hline & & & \multicolumn{2}{|c|}{$200^{\circ} \mathrm{C}$} & \multicolumn{2}{|c|}{$400^{\circ} \mathrm{C}$} & \multicolumn{2}{|c|}{$600^{\circ} \mathrm{C}$} \\
\hline & & & $\begin{array}{c}\text { Before } \\
\text { (g) }\end{array}$ & $\begin{array}{c}\text { After } \\
\text { (g) }\end{array}$ & $\begin{array}{c}\text { Before } \\
\text { (g) }\end{array}$ & $\begin{array}{c}\text { After* } \\
\text { (g) }\end{array}$ & $\begin{array}{c}\text { Before } \\
\text { (g) }\end{array}$ & $\begin{array}{l}\text { After* } \\
\text { (g) }\end{array}$ \\
\hline \multirow[t]{6}{*}{ A } & Test & $\mathrm{P}$ & 2433.5 & 2359.4 & 2441.1 & - & 2465.5 & - \\
\hline & 1 & Q & 2432.4 & 2353.3 & 2457.2 & - & 2443.6 & - \\
\hline & & & 2466.3 & 2380.3 & 2456.5 & - & 2449.5 & - \\
\hline & & & 2455.4 & 2354.5 & 2453.5 & - & 2438.3 & - \\
\hline & Test & $\mathrm{P}$ & & & & & & \\
\hline & 2 & Q & & & & & & \\
\hline \multirow[t]{6}{*}{ B } & Test & $P$ & 2465.5 & 2369.3 & 2463.8 & - & 2467.4 & - \\
\hline & 1 & Q & 2465.4 & 2368.7 & 2446.3 & - & 2398.7 & - \\
\hline & & & 2338.4 & 2269.2 & 2368.7 & - & 2346.8 & - \\
\hline & & & 2348.4 & 2279.5 & 2351.4 & - & 2348.8 & - \\
\hline & Test & $\mathrm{P}$ & & & & & & \\
\hline & 2 & Q & & & & & & \\
\hline
\end{tabular}

* samples were destroyed beyond recovery

Figure 11 shows that the concrete lost some mass at 200 ${ }^{\circ} \mathrm{C}$. 


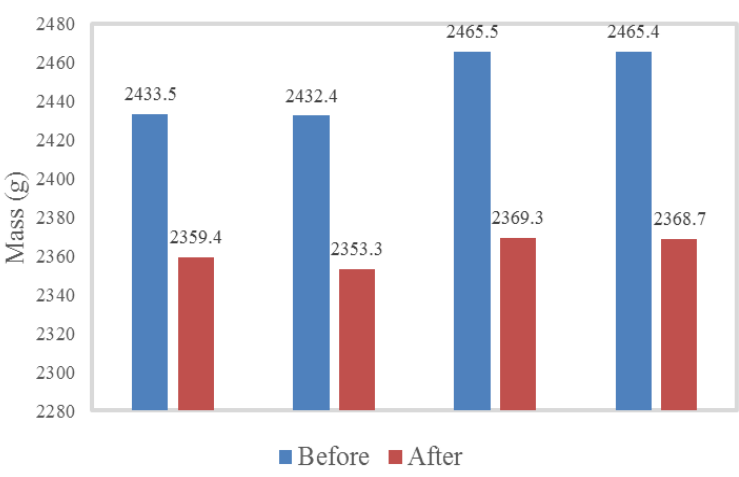

Figure 11. Residual mass of UHPFRC before and after $200{ }^{\circ} \mathrm{C}$ furnace test 1 .

This result is attributed to losses in the water content of the concrete. This behavior is similar to test 2 . Mass loss determination could not be completed at 400 and $600{ }^{\circ} \mathrm{C}$ because of complete deterioration of the specimens under high temperature.

Representative samples of specific batch mixes were taken for compressive strength determination before the test. The average strength was taken from two samples. Strength loss was not apparent when subjected to a low temperature loading of $200{ }^{\circ} \mathrm{C}$. However, severe spalling behavior at high temperatures of 400 and $600{ }^{\circ} \mathrm{C}$ made a compressive strength test impossible to perform. Figure 12 shows a cubic sample subjected to compressive strength after heating at $200{ }^{\circ} \mathrm{C}$.

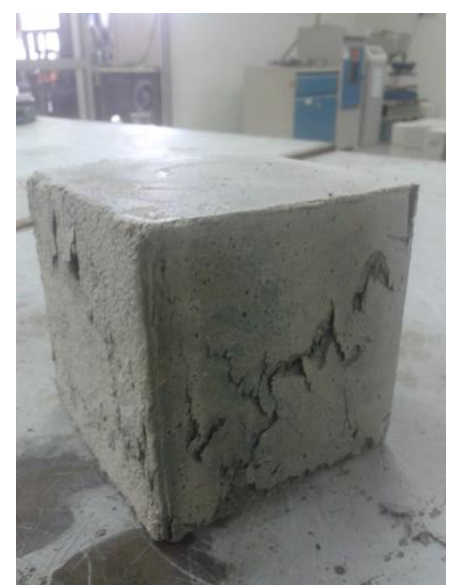

Figure 12. UHPFRC subjected to compressive strength testing after heating at $200{ }^{\circ} \mathrm{C}$.

The figure 12 shows the failure mode of the crack due to the compressive test. The sample fared well in compressive strength test, and nearly no strength loss was detected. Table 7 summarizes the strength loss before and after the furnace test. No compressive strength was obtained after 400 and $600{ }^{\circ} \mathrm{C}$ because of sample deterioration.
Table 7. Strength loss of UHPFRC of various mix designs before and after furnace test.

\begin{tabular}{|c|c|c|c|c|c|c|c|}
\hline \multicolumn{2}{|c|}{ Mix Type } & \multicolumn{6}{|c|}{ Temperature } \\
\hline & & \multicolumn{2}{|c|}{$200^{\circ} \mathrm{C}$} & \multicolumn{2}{|c|}{$400^{\circ} \mathrm{C}$} & \multicolumn{2}{|c|}{$600^{\circ} \mathrm{C}$} \\
\hline & & $\begin{array}{l}\text { Before } \\
(\mathrm{MPa})\end{array}$ & $\begin{array}{l}\text { After } \\
(\mathrm{MPa})\end{array}$ & $\begin{array}{l}\text { Before } \\
\text { (MPa) }\end{array}$ & $\begin{array}{l}\text { After* } \\
\text { (MPa) }\end{array}$ & $\begin{array}{l}\text { Before } \\
(\mathrm{MPa})\end{array}$ & $\begin{array}{l}\text { After* } \\
(\mathrm{MPa})\end{array}$ \\
\hline \multirow[t]{3}{*}{ A } & Test & 157 & 155 & 157 & - & 157 & - \\
\hline & 1 & 154 & 151 & 154 & - & 154 & - \\
\hline & Test & & & & & & \\
\hline \multirow[t]{3}{*}{ B } & Test & 162 & 161 & 162 & - & 162 & - \\
\hline & 1 & 163 & 161 & 163 & - & 163 & - \\
\hline & $\begin{array}{c}\text { Test } \\
2\end{array}$ & & & & & & \\
\hline
\end{tabular}

* samples were destroyed beyond recovery

\subsection{BS 476 fire tests on building materials and structures: Part 4}

Table 8 shows a summary of the results. The test results were inconclusive because all samples exploded within a few minutes.

Table 8. Test results of non-combustibility test.

\begin{tabular}{|c|c|c|c|c|c|c|c|}
\hline Parameters & \multirow[t]{2}{*}{ Units } & \multirow{2}{*}{\multicolumn{2}{|c|}{1}} & \multirow{2}{*}{\multicolumn{2}{|c|}{2}} & \multirow{2}{*}{\multicolumn{2}{|c|}{3}} \\
\hline $\begin{array}{l}\text { Specimen } \\
\text { Reference }\end{array}$ & & & & & & & \\
\hline Weight & $\mathrm{g}$ & \multicolumn{2}{|c|}{209.65} & \multicolumn{2}{|c|}{201.70} & \multicolumn{2}{|c|}{204.60} \\
\hline $\begin{array}{l}\text { Width \& } \\
\text { Breadth }\end{array}$ & $\mathrm{mm}$ & \multicolumn{2}{|c|}{$40 \times 40$} & \multicolumn{2}{|c|}{$40 \times 40$} & \multicolumn{2}{|c|}{$40 \times 40$} \\
\hline Height & $\mathrm{mm}$ & \multicolumn{2}{|l|}{50} & \multicolumn{2}{|l|}{50} & \multicolumn{2}{|l|}{50} \\
\hline Density & $\mathrm{kg} / \mathrm{m}^{3}$ & \multicolumn{2}{|c|}{2620.63} & \multicolumn{2}{|c|}{2521.25} & \multicolumn{2}{|c|}{2557.50} \\
\hline $\begin{array}{l}\text { Average } \\
\text { Density }\end{array}$ & $\mathrm{kg} / \mathrm{m}^{3}$ & \multicolumn{6}{|c|}{2566.46} \\
\hline $\begin{array}{l}\text { Temp. } \\
\text { Measurement* }\end{array}$ & & & $\begin{array}{l}\mathrm{CH} \\
2\end{array}$ & $\begin{array}{l}\mathrm{CH} \\
1\end{array}$ & $\begin{array}{l}\mathrm{CH} \\
2\end{array}$ & $\begin{array}{l}\mathrm{CH} \\
1\end{array}$ & $\begin{array}{l}\mathrm{CH} \\
2\end{array}$ \\
\hline $\begin{array}{l}\text { Max. Furnace } \\
\text { Temp. }\end{array}$ & ${ }^{\circ} \mathrm{C}$ & $*$ & $*$ & $*$ & $*$ & $*$ & $*$ \\
\hline $\begin{array}{l}\text { Stabilized } \\
\text { Temp. }\end{array}$ & ${ }^{\circ} \mathrm{C}$ & \multicolumn{2}{|l|}{750} & \multicolumn{2}{|l|}{750} & \multicolumn{2}{|l|}{750} \\
\hline $\begin{array}{l}\text { Temp. } \\
\text { Difference }\end{array}$ & ${ }^{\circ} \mathrm{C}$ & - & - & - & - & - & - \\
\hline
\end{tabular}

The non-combustibility test was deemed invalid. The sample totally disintegrated in the furnace within a few minutes and the test could not be completed. Similar to the furnace test performed previously, UHPFRC did not perform well under high temperatures. The specimen underwent explosive spalling and could not be recognized. Before the test, specimens was dried in a ventilated oven at $60 \pm 5{ }^{\circ} \mathrm{C}$ for $24 \mathrm{~h}$ and then cooled to ambient temperature in a desiccator. Explosive spalling was attributed solely to the build-up of pressure from steam that had no exit route because of the low porosity of UHPFRC. This problem must be addressed to commercialize UHPFRC in the industry for public safety. To overcome this problem, the bond between the matrix and steel fibers as well as quartz sand particles must be exceptionally strong. Polypropylene fibers could enhance 
the fire resistibility of UHPFRC and may be used alongside steel fibers.

\subsection{BS 476 fire tests on building materials and structures: Part 6}

The purpose of this test is to obtain a fire propagation index, which provides a comparative measure of the contribution to the growth of fire. Comparison is performed against a calibration sheet, in this case, an asbestos sheet, and the temperature rise was recorded accordingly. Three specimens measuring $225 \mathrm{~mm} \times 225 \mathrm{~mm} \times 50 \mathrm{~mm}$ were tested, and their average density was $2316 \mathrm{~kg} / \mathrm{m}^{3}$. The test apparatus consisted of a combustion chamber with a specimen holder fixed to one face. The combustion chamber contained a horizontal gas burner tube and two electrical heating elements, and was surmounted by a removable steel chimney and cowl. The rise in temperature of the specimen was recorded using a thermocouple located on the cowl. During heating, three sub-indices, namely, $S_{l}$, $\mathrm{S}_{2}$, and $\mathrm{S}_{3}$ were calculated. These sub-indices are defined as follows:

$$
\begin{aligned}
& S_{1}=\sum_{t=0.5}^{t=3} \frac{\theta_{s}-\theta_{c}}{10 t} ; \\
& S_{2}=\sum_{t=4}^{t=10} \frac{\theta_{s}-\theta_{c}}{10 t} ; \\
& S_{3}=\sum_{t=12}^{t=20} \frac{\theta_{s}-\theta_{c}}{10 t} ;
\end{aligned}
$$

where

$\theta_{s}$ is the actual temperature rise of the specimen to the nearest ${ }^{\circ} \mathrm{C}$

$\theta_{c}$ is the actual temperature rise of the calibration material to the nearest ${ }^{\circ} \mathrm{C}$

$t$ is the time, in min, of the specified interval

Once the sub-indices were calculated, the index of overall performance, also known as the fire propagation index, $i$, was calculated from these sub-indices. The relevant formula for $i$ is as follows:

$$
I=i_{1}+i_{2}+i_{3}
$$

where

$i_{1}=\frac{1}{3}\left[\left(S_{1}\right)_{A}+\left(S_{1}\right)_{B}+\left(S_{1}\right)_{C}\right]$
$i_{2}=\frac{1}{3}\left[\left(S_{2}\right)_{A}+\left(S_{2}\right)_{B}+\left(S_{2}\right)_{C}\right]$
$i_{3}=\frac{1}{3}\left[\left(S_{3}\right)_{A}+\left(S_{3}\right)_{B}+\left(S_{3}\right)_{C}\right]$

where $\mathrm{A}, \mathrm{B}$, and $\mathrm{C}$ represent individual specimens yielding valid test results, and $S_{1}, S_{2}$, and $S_{3}$ are the subindices.

As shown in Table 9, the sub-indices for all three specimens were 0.0 except sub-index 2 of specimen $\mathrm{C}$, which was 0.1 or negligible in reality. The $i$ is also 0.0 .
Table 9. Results of the fire propagation test.

\begin{tabular}{|c|c|c|c|c|c|}
\hline $\begin{array}{c}\text { Time } \\
(\mathrm{min})\end{array}$ & Calibration & $\begin{array}{c}\text { Specimen } \\
\text { A }\end{array}$ & $\begin{array}{c}\text { Specimen } \\
\text { B }\end{array}$ & $\begin{array}{c}\text { Specimen } \\
\text { C }\end{array}$ & $\begin{array}{c}\text { Specimen } \\
\text { Average }\end{array}$ \\
\hline 0.5 & 14 & 11 & 9 & 8 & 9 \\
1.0 & 17 & 15 & 12 & 12 & 13 \\
1.5 & 22 & 18 & 16 & 15 & 16 \\
2.0 & 25 & 20 & 18 & 17 & 18 \\
2.5 & 29 & 22 & 19 & 20 & 20 \\
3.0 & 34 & 25 & 25 & 29 & 26 \\
4.0 & 68 & 57 & 64 & 70 & 64 \\
5.0 & 104 & 87 & 96 & 99 & 94 \\
6.0 & 129 & 108 & 116 & 123 & 115 \\
7.0 & 153 & 128 & 133 & 143 & 134 \\
8.0 & 170 & 143 & 151 & 158 & 151 \\
9.0 & 187 & 157 & 163 & 174 & 164 \\
10.0 & 203 & 167 & 173 & 183 & 174 \\
12.0 & 222 & 191 & 193 & 200 & 194 \\
14.0 & 232 & 201 & 204 & 214 & 206 \\
16.0 & 245 & 206 & 214 & 225 & 215 \\
18.0 & 253 & 214 & 220 & 229 & 221 \\
20.0 & 258 & 218 & 220 & 236 & 225 \\
\hline \multicolumn{2}{|c|}{ Subindex 1 } & 0.0 & 0.0 & 0.0 & 0.0 \\
Subindex 2 & 0.0 & 0.0 & 0.1 & 0.0 \\
Subindex 3 & 0.0 & 0.0 & 0.0 & 0.0 \\
\hline \multicolumn{2}{|c|}{ Index of } & 0.0 & 0.0 & 0.1 & 0.0 \\
\hline \multicolumn{2}{|c|}{ Performance } & & & & \\
\hline
\end{tabular}

As shown in Figure 13, the temperature of UHPFRC does not rise as quickly as that in the calibration material.

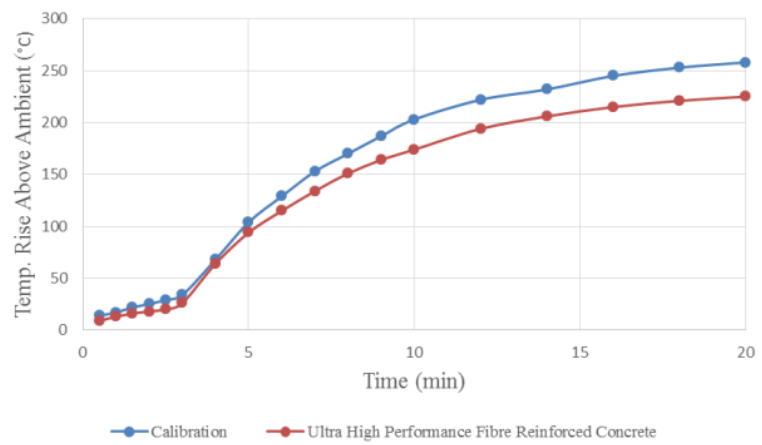

Figure 13. Graph of temperature rise of UHPFRC vs. calibration.

Asbestos sheeting is a common material used in wall and ceiling claddings. Thus, using UHPFRC as a structural or non-structural component resists the growth of fire even if the claddings are in flames. The highest average temperature rise of UHPFRC above the ambient temperature $\left(25^{\circ} \mathrm{C}\right)$ recorded over a $20 \mathrm{~min}$ time frame is $225^{\circ} \mathrm{C}$, which is lower than the calibration material's 258 ${ }^{\circ} \mathrm{C}$. The specimens performed exceptionally well. No spalling was observed. An $i$ of 0.0 is the best index possible given the conditions of this test. Although the behavior of UHPFRC toward fire in this test was good, the results should not be the sole criterion for assessing the potential fire hazard of the product in use. 


\subsection{BS 476 fire tests on building materials and structures: Part 7}

This test measures the lateral spread of flame along the surface of UHPFRC specimens and enables classification of the sample based on the rate and extent of the flame. This classification would allow UHPFRC to be compared with other products on the basis of their fire performance when used as exposed surfaces of walls or ceilings. Four classes, Classes 1-4, have been specified and Class 1 is the class with the best fire performance. The classes are solely based on the spread of flame. Table 10 demonstrates how the code classifies the spread of flame. Six specimens measuring $885 \mathrm{~mm} \times 225 \mathrm{~mm} \times 50$ $\mathrm{mm}$ were used. The average density of the specimens was $2313 \mathrm{~kg} / \mathrm{m}^{3}$. Test results indicated that the specimens may be classified under Class 1, which features the shortest distance travelled and slowest flame spread. Table 10 shows a summary of the results of the flame test.

Table 10. Classification of spread of flame.

\begin{tabular}{|l|l|l|l|l|}
\hline Classification & \multicolumn{3}{|l|}{$\begin{array}{l}\text { Spread of flame at 1.5 } \\
\text { min }\end{array}$} & $\begin{array}{l}\text { Final spread of flame } \\
(10 \mathrm{~min})\end{array}$ \\
\hline & $\begin{array}{l}\text { Limit } \\
(\mathrm{mm})\end{array}$ & $\begin{array}{l}\text { Limit for } \\
\text { one } \\
\text { specimen in } \\
\text { sample } \\
(\mathrm{mm})\end{array}$ & $\begin{array}{l}\text { Limit } \\
(\mathrm{mm})\end{array}$ & $\begin{array}{l}\text { Limit for } \\
\text { one } \\
\text { specimen } \\
\text { in sample } \\
(\mathrm{mm})\end{array}$ \\
\hline Class 1 & 165 & $165+25$ & 165 & $165+25$ \\
\hline Class 2 & 215 & $215+25$ & 455 & $455+45$ \\
\hline Class 3 & 265 & $265+25$ & 710 & $710+75$ \\
\hline Class 4 & \multicolumn{5}{|l|}{ Exceeding the limits for class 3 } \\
\hline
\end{tabular}

Under a Class 1 fire rating, UHPFRC can reasonably protect against the spread of flame; this rating is the best class possible under the provisions of the BS476 code. The specimens exhibited exceptionally behavior in resisting flame. This result indicates that the specimens show no signs of fire spread. After the first 90 $\mathrm{s}$ of testing, no flame ignition was observed on the specimens. This phenomenon continued until the end of the 10 min test. The resistance of UHPFRC to fire spread is highly typical of the natural fire resistance concrete.

\section{Conclusions}

UHPFRC performed exceptionally well at $200{ }^{\circ} \mathrm{C}$. Its compressive strength was not compromised and the material did not spall, although some mass loss attributed to water loss was observed. Explosive spalling was observed at temperatures beginning from $400{ }^{\circ} \mathrm{C}$ and above. The presence of steel fibers did not contribute to prevent explosive spalling.

Strength loss was imminent when UHPFRC underwent explosive spalling at temperatures above $400{ }^{\circ} \mathrm{C}$. The material disintegrated, leaving no core sample to be tested. No compressive strength was left to be recovered.

UHPFRC can neither be classified as a combustible nor non-combustible material. The non-combustibility test had to be stopped because the material was no longer suitable to carry out the test because of explosive spalling. However, UHPFRC showed excellent performance in resisting heat when heated at low temperatures. The temperature rise was not prominent, which indicates that UHPFRC is an excellent material for resisting the growth of fire. UHPFRC scored a Fire Propagation Index $I$ of 0.0 , the best index available under BS476 Part 6, and showed excellent resistance to flame spread. No flame was observed to spread on the material when the pilot flame was ignited. Thus, the material was given a Class 1 fire rating under BS476 Part 7.

\section{Acknowledgement}

This research was supported by Universiti Sains Malaysia under Research University Individual grant (814190).

\section{References}

1. N. Krstulovic-Opara, E. Dogan, C.M. Uang, A.R. Haghayeghi, Flexural behavior of composite RCSlurry infiltrated mat concrete (SIMCON) members, ACI Structure Journal, 94 (1997).

2. J.H.J. Kim, Y.M. Lim, J.P. Won, H.G. Park, K.M. Lee, Shear capacity and failure behavior of DFRCC repaired $R C$ beams at tensile region, Engineering Structure 29 (1) 121-31 (2007).

3. K. Habel, E. Denarié, E. Brühwiler, Experimental investigation of composite UHPFRC concretre members, ACI Structure journal, 104 (1) 93-101 (2007).

4. B.A. Graybeal, Compressive behaviour of UltraHigh-Performance Fibre-Reinforced Concrete, ACI materials journal, 40, 104-107 (2007).

5. O. Million, W. Riedel, C. Mayrhofer, K. Thoma, Fibre-reinforced ultra-high performance concrete-a material with potential for protective structures, Proceeding of the first international conference of protective structures, Manchester, 103 (2010).

6. Y. Uchida, J. Niwa, Y. Tanaka, M. Katagiri, G. Fischer, V. Li, Recommendations for design and construction of ultra high strength fibre reinforced concrete structures, Concrete committee of Japan Society of Civil Engineers (JSCE), 345-351 (2006).

7. G.A. Parsekian, N.G. Shrive, T.G. Brown, J. Kroman, P.J. Seibert, V.H. Perry, A. Boucher, Innovative ultra-high performance concrete structures, Tailor Made Concrete Structures, Taylor\&Francis Group, London, 325-330 (2008).

8. B.A. Graybeal, MAterial property characterization of ultra-high performance concrete FHWA-HRT-06103, Faderal highway administration, Washington, DC (2006).

9. N. Wang, S. Mindess, K. Ko, Fibre reinforced concrete beams under impact loading, Cement \& Concrete research, 26, 363-376 (1996).

10. A.H. Akca, N.O. Zihnioğlu, High performance concrete under elevated temperatures, Construction and building materials, 44, 317-328 (2013). 
11. J. J, Park, D. Yoo, S.W. Kim, Y.S. Yoon, Drying shrinkage cracking characteristics of ultra-high performance fibre reinforced concrete with expansive and shrinkage reducing agents. Magazine of concrete research 65, 248-256 (2013).

12. R. Yu, P. Spiesz, H.J.H. Brouwers, Mix design and properties assessment of Ultra-high performance fibre reinforced concrete (UHPFRC), Cemented concrete research, 56, 29-39 (2013). 